\title{
Effect of artificial feeders on pollen loads of the hummingbirds of Cerro de La Muerte, Costa Rica
}

\author{
Gerardo Avalos ${ }^{1,2}$, Alejandra Soto ${ }^{3} \&$ Willy Alfaro ${ }^{4}$ \\ 1. Escuela de Biología, Universidad de Costa Rica, 2060 San Pedro, San José, Costa Rica. \\ 2. The School for Field Studies, Center for Sustainable Development Studies, 10 Federal St., Salem, MA 01970 USA; \\ avalos@fieldstudies.org \\ 3. Elon University, Ecology and Environmental Science, Apdo. 1524-2050 San Pedro, Costa Rica; alekasoto@gmail.com \\ 4. Apdo.463, San Ramón, 20203, Costa Rica; willyalfaro@amnet.co.cr
}

Received 01-III-2011. Corrected 10-VI-2011. Accepted 11-VII-2011.

\begin{abstract}
Although sugar-water feeders are commonly used by enthusiasts to attract hummingbirds, little is known about how they affect hummingbird behavior and flower use. We studied the highland hummingbird assemblage of Cerro de La Muerte, Costa Rica, both at a site with permanent feeders (La Georgina Restaurant) and further from it. We examined how feeder use and monopolization affected seasonal changes in pollen loads during four sampling periods, including dry and wet seasons, from 2003-2005. We expected that species monopolizing the feeders would carry little or no pollen whatsoever, and would have pollen loads characterized by low floral diversity, in contrast with species less dependent on feeders. We obtained pollen samples from 183 individuals of four hummingbird species captured around the feeders using mist nets, which were compared with a pollen reference collection of plants with a pollination syndrome by hummingbirds. The same methods were implemented at a site $3 \mathrm{~km}$ away from the feeders. Feeder usage was quantified by counting the number of times hummingbirds drank from the feeders in periods of $4 \mathrm{~min}$ separated by $1 \mathrm{~min}$. The effects of hummingbird species and season on pollen load categories were assessed using a nominal logistic regression. The alpha species at the site, the Fiery-throated Hummingbird (Panterpe insignis), dominated the feeders during the dry season. Meanwhile, in the wet season, feeder usage was more evenly distributed across species, with the exception of the Volcano Hummingbird, Selasphorus flammula, which occupies the last place in the dominance hierarchy. Pollen loads of hummingbirds captured near feeders were low in abundance (more than $50 \%$ of captured individuals had zero or low pollen loads), and low in species richness ( $96 \%$ of the hummingbirds with pollen from only one plant genus, Centropogon). Overall pollen loads increased during the dry season coinciding with peaks in flower availability, although the majority of captured hummingbirds carried no pollen. Mist nets located $3 \mathrm{~km}$ from La Georgina returned few captures (one-to-three specimens) per sampling date, contrasting with observations made before feeders were present. These results suggest that sugar-water feeders gather hummingbirds in over considerable distances drawing them away from flowers. The competitive and antagonistic pattern shown between feeders and flowers indicate that natural pollination system could be significantly altered. Supplementing hummingbirds with food seems likely to interfere with pollination networks already stressed by many anthropogenic effects. Rev. Biol. Trop. 60 (1): 65-73. Epub 2012 March 01.
\end{abstract}

Key words: Panterpe insignis, Eugenes fulgens, Selasphorus flammula, Colibri thalassinus, Cerro de la Muerte, artificial feeders, pollen loads, foraging ecology.

High elevation imposes major physiological challenges on hummingbirds, a group already characterized by having one of the highest metabolic rates found in vertebrates, which combined with their small size and low volume to surface ratio favors a rapid loss of body heat (Alshuler \& Dudley 2002). The 52 species of hummingbirds found in Costa Rica are mostly abundant in lowland and premontane tropical forests, and their diversity decreases with increasing elevation. This is consistent with the Amazonian origin of the 
family Trochilidae, and the inferred pattern of subsequent colonization of new habitats, including highlands, as the family diversified (Bleiweiss 1998). To cope with the harsh conditions of high elevations, hummingbirds rely on nectar, which provides a predictable source of energy. In addition, torpor allows hummingbirds to reduce body temperature during very cold nights thus saving energy (Hainsworth et al. 1977), and species that inhabit high elevations also exhibit changes in morphology that reduce energy consumption during hovering flight (Alshuler \& Dudley 2002). Floral nectar, which provides a concentrated source of energy, is another factor in allowing the colonization of harsh environments, including high elevations. Although, foraging on insects by hummingbirds is common, and provides a critical source of protein for growth and reproduction (Poulin et al. 1992, Stiles 1995), insects do not substitute for floral nectar (Brice 1992), and nectar availability drives the annual cycles of most hummingbird species (Stiles 1980), especially in the highlands (Hainsworth \& Wolf 1972).

An increasing number of restaurants, hotels and recreational areas, as well as numerous hummingbird enthusiasts, maintain sugarwater hummingbird feeders on a permanent basis. The underlying reasons for establishing feeders range from purely economical (a tourist attraction) to the general belief that the practice benefits the hummingbirds. Feeders satisfy the thrill of attracting birds that are often difficult to observe in high numbers under natural conditions. Notwithstanding this practice is widespread, and feeders are regularly used in ecological (Powers 1987) and ecophysiological research (Stromberg \& Johnsen 1990, Sandlin 2000), including banding studies (Inouye et al. 1991), little is known of the consequences of the continuous use of commercial feeders for the biology of hummingbirds or for the reproductive success of their associated plants (Arizmendi et al. 2007, McCaffrey \& Wethington 2008). Pollinator diversion by feeder usage is more likely to affect pollination systems in the highlands, where harsh environmental conditions impose significant energy constraints on pollinators.

The objective of this study was to assess how the use of artificial sugar-water feeders influences the quantity and composition of pollen loads of the hummingbirds in the highlands of Cerro de La Muerte, Costa Rica. Since 2001, the restaurant La Georgina in Cerro de La Muerte has maintained up to 15 permanent hummingbird feeders. We expected species monopolizing the feeders to carry no pollen or small pollen loads representing a low diversity of plant species, in comparison with species that made less use of the feeders. We also sampled hummingbirds at a site $3 \mathrm{~km}$ away from La Georgina.

\section{MATERIALS AND METHODS}

Study site: The study was carried out at La Georgina Restaurant and Lodge in Cerro de la Muerte, Cartago, Costa Rica (3 086masl, $09^{\circ} 33^{\prime} 28^{\prime \prime} \mathrm{N}-83^{\circ} 43$ '25" W) in the Talamanca Mountain Range. This region is dominated by oak forests and páramo ecosystems. Temperatures range from $25^{\circ} \mathrm{C}-0^{\circ} \mathrm{C}$ (Wolf et al. 1976), but may approach $-5^{\circ} \mathrm{C}$ before dawn and $28^{\circ} \mathrm{C}$ at midday during the dry season. The dry season lasts from November-April, and the wet season reaches a peak during September-October.

We sampled four periods over two years: July 30-31, 2003 (wet season 2003); November 11-12, 2004 (early dry season 2004); February 11-12, 2005 (peak dry season 2005); and September 20-21, 2005 (peak wet season 2005). Four species of hummingbirds are regular residents: the Volcano (Selasphorus flammula), Fiery-throated (Panterpe insignis), Magnificent (Eugenes fulgens) and Green Violet-eared (Colibri thalassinus) hummingbirds. All these species are able to move across elevations following changes in nectar resources (Stiles \& Skutch 1989). The ecological relationships and hierarchy of dominance are described by Wolf et al. (1976) and Colwell (1973). P. insignis is the alpha species, followed by $C$. thalassinus, E. fulgens and S. flammula. 
Quantification of feeder visitation: For each sample we visited La Georgina for two days. Data were collected in the vicinity of the restaurant in the afternoon of the first day (from 14pm-18pm) and during the morning of the second day (from 7am-13am). All 15 feeders were filled up with the same sugar solution by the restaurant owners, and were presented to the hummingbirds at 6am and were refilled around $13 \mathrm{pm}$ every day of the year. Feeders were located at approximately $8 \mathrm{~m}$ above the ground, immediately outside the windows on the second floor of the restaurant, in an area overlooking a large cattle pasture and the oak forest beyond. Feeders were evenly spaced by $1.5 \mathrm{~m}$.

For $1 \mathrm{~min}$, every $4 \mathrm{~min}$, we recorded the species and number of individuals per species that drank from every feeder simultaneously. A "visit" took place when the hummingbird drank directly from the feeder. Multiple dips into the feeder were counted as individual visits. This procedure measured only the actual use of the feeders by the hummingbirds. It did not take into account interference interactions, such as deterring other hummingbirds from using the feeders by perching on or hovering around them.

Pollen loads: We captured hummingbirds with three to four mist nets of $10 \mathrm{~m} \times 2.5 \mathrm{~m}$ set up close to the hummingbird feeders at La Georgina, as well as $3 \mathrm{~km}$ away from the Restaurant in the edge between a cattle pasture and the oak forest following the same schedule as the feeder observations (see above) at both locations. We used nail polish of different colors to leave a painted mark on the hummingbird toenails using a unique color and digit combination for each individual at each sampling date. We made sure that the nail polish dried up before a bird was released. To collect pollen samples, one piece of transparent Scotch ${ }^{\mathrm{TM}}$ tape per individual was dabbed gently against the bird's throat, forehead, chest, nape and beak, and then placed on a glass microscope for later inspection and identification of the pollen type. Hummingbirds with no pollen at all were recorded as "Zero", those with five or less pollen grains per slide were classified as "Low", and those with more than five pollen grains were classified as "High". These categories matched our former field observations before the establishment of the feeders, with hummingbirds having high pollen loads showing clusters of pollen that clearly surpassed the lower limit for the "High" score category.

Pollen reference collection: Pollen samples were collected from open flowers of plants identified to be hummingbird pollinated (Wolf et al. 1976), to establish a pollen reference collection. We opened ripe anthers onto a microscope slide and sealed each sample with a piece of transparent Scotch ${ }^{\mathrm{TM}}$ tape. Pollen was identified under a light microscope, and drawings and digital photos of pollen grains were made to identify to genus (and species when possible) the pollen grains carried by hummingbirds.

Statistical analyses: We used a chi-square test to look for variation among hummingbird species and seasons in the frequency of feeder visitation. To determine differences in the frequency of occurrences of categories of pollen loads among species and seasons we used a nominal $\operatorname{logistic}$ regression of the form $\log (\mathrm{P})$ ${ }_{i j}=b o+b_{1} X_{i}+b_{2} X_{j}+e_{i j}$, where $P$ is the probability of occurrence of a given pollen load category for a given season $\mathrm{x}$ species combination, $\mathrm{X}_{\mathrm{i}}$ is the effect of the species, and $X_{j}$ is the effect of the season (sampling period), and $\mathrm{e}_{\mathrm{ij}}$ is the error term. Due to the low frequency of $S$. flammula visits, we excluded that species from the analysis. The number of hummingbirds captured away from La Georgina was small (one to three individuals per sampling period), preventing the inclusion of these data in further statistical analyses. All analyses were carried out using JMP 7.0 (SAS Institute, Cary, North Carolina, USA). 


\section{RESULTS}

Feeder visitation: Throughout the early dry season of 2004 and the peak dry season of 2005 P. insignis was by far the most dominant hummingbird at the feeders, while $S$. flammula made the least use of the feeders across all seasons. E. fulgens, $P$. insignis and $C$. thalassinus made a similar use of feeders during the peak 2005 wet season (Table 1). Feeder usage was clearly dependent on season and hummingbird species $\left(\chi^{2}=463.92, \mathrm{p}<0.001\right.$, $\mathrm{df}=6$ ). In addition, $S$. flammula made a greater percentage of the total visits during the peak wet season than in the early dry or peak dry seasons (Table 1). The feeders attracted a large number of hummingbirds, and although we did not count how many hummingbirds of each species were using the feeders, we feel that the patterns of feeder monopolization closely resembled the abundance of each hummingbird species around the feeders, as well as of those captured in the mist nets. Most hummingbirds quit $15 \mathrm{~min}$ before sunset, with only a few $P$. insignis remaining at the feeders for at least 15 more minutes after dusk.

Pollen loads: Of the 183 hummingbirds captured in the mist nets over the course of the study 12 were recaptures, and were excluded from further analyses. No individual captured at La Georgina was recaptured at our site $3 \mathrm{~km}$ away from the feeders.

More than $50 \%$ of the birds captured at each sampling period had zero or low pollen loads (Fig. 1, Table 2). If the "zero" and "low" categories are combined (or if only the "high" category is considered), the percentage carrying little pollen increases to $70 \%$ of the captured birds. Furthermore, only four E. fulgens carried mites on their beaks (the presence of mites is evidence of flower visitation).

Logistic regression showed a significant effect of season (Wald test $=18.38, \mathrm{p}=0.005$, $\mathrm{df}=6$ ), but not of species (Wald test $=3.41$, $\mathrm{p}=0.49, \mathrm{df}=4)$, indicating that patterns of pollen loads were similar for the three species considered in the analysis ( $P$. insignis, $C$. thalassinus and E. fulgens). The effect of season continued to be significant even after excluding $C$. thalassinus from the analysis (Wald test=16.69, $\mathrm{p}=0.01, \mathrm{df}=6$ ) since this species was not captured either in the 2003 wet season or in the 2004 early dry season (Table 2). The percentage of hummingbirds with high pollen loads was greatest during the peak dry season of 2005, although most hummingbirds still carried zero pollen. The lowest pollen loads were observed during the peak wet season of 2005. For this period, there was a reduction in the number of individuals per species with the exception E. fulgens (Table 1). Of the four species, $P$. insignis and E. fulgens had the highest proportion of individuals with zero pollen across sampling dates. Consistent with our expectation, in the early 2004 dry season E. fulgens decreased its utilization of feeders, and the number of individuals with high pollen loads increased (Table 2). In the peak dry season of 2005 P. insignis and E. fulgens had relatively equal proportions of birds with zero pollen. Similar patterns were found for $C$. thalassinus

TABLE 1

Total number of feeder visits by hummingbird species (percentage of total per sampling date) from 2004 to 2005 at La Georgina, Cerro de La Muerte, Costa Rica

\begin{tabular}{lccc}
\multicolumn{1}{c}{ Species } & & Number of Feeder Visits & \\
& 2004 early dry season & 2005 peak dry season & 2005 peak wet season \\
Panterpe insignis & $1611(41)$ & $1829(42)$ & $2511(27)$ \\
Colibri thalassinus & $846(22)$ & $853(20)$ & $2347(25)$ \\
Eugenes fulgens & $938(24)$ & $1098(26)$ & $2759(30)$ \\
Selasphorus flammula & $513(13)$ & $506(12)$ & $1692(18)$ \\
Total numbers & 3908 & 4286 & 9309 \\
\hline
\end{tabular}



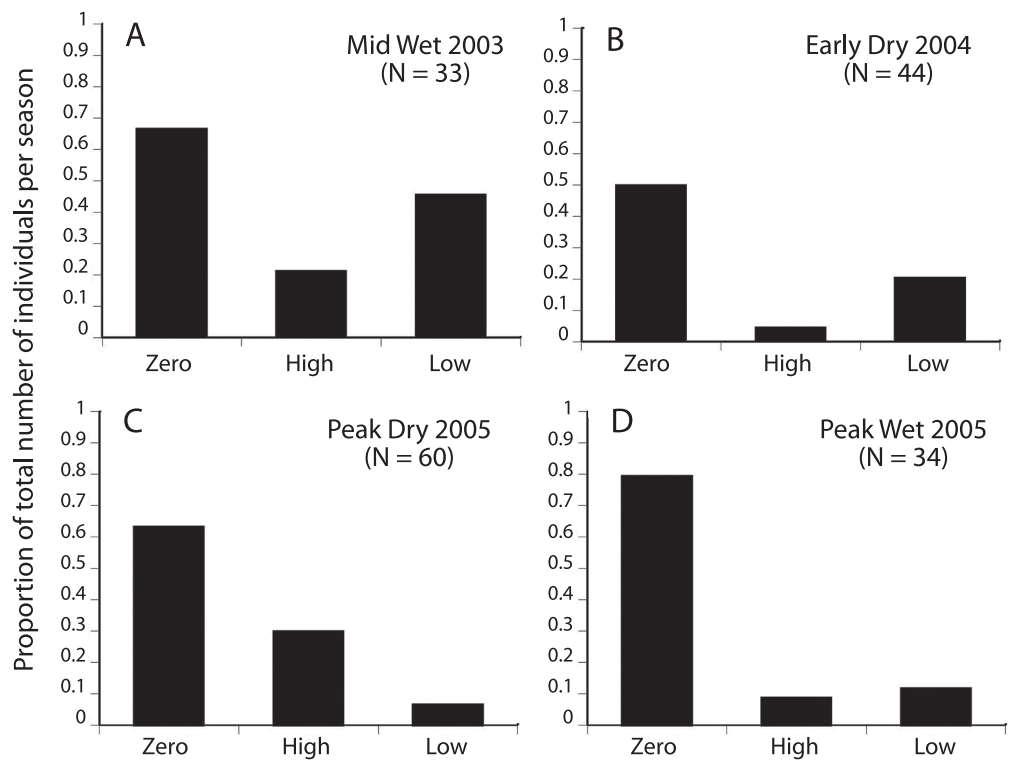

Fig. 1. Proportion of pollen loads per sampling season across species of highland hummingbirds of Cerro de La Muerte Costa Rica.

and S. flammula, although these two species were not well represented in the mist net data.

\section{Plant species represented in pollen loads:}

Species of Centropogon (C. talamancensis and C. valerii) dominated $61 \%$ of the pollen loads taken at La Georgina across sampling periods; pollen of other plant species was uncommon (Table 3). $96 \%$ of hummingbirds that carried pollen carried only one species. Mist nets located away from the Restaurant returned a low number of hummingbirds captured per sampling date (one-to-three specimens, with high pollen loads, mostly from Centropogon). Although we increased the distance from the Restaurant area, and set up the mist nets in habitats where hummingbirds were observed to be formerly abundant (forest edges, abandoned pastures with abundance of hummingbird pollinated plants), the return in numbers of captured hummingbirds was low during the sampling period (total $\mathrm{n}=10$ ).

\section{DISCUSSION}

According to this study, sugar-water feeders appear to have the ability to attract hummingbirds across considerable distances, drawing them away from flowers, at least in some seasons. We captured few hummingbirds at a site $3 \mathrm{~km}$ from the La Georgina feeders, and sampling of other habitats away from the Restaurant failed to alter this pattern. No hummingbird captured at La Georgina was recaptured away from the Restaurant. Most hummingbirds captured at feeders carried little pollen, or no pollen whatsoever. The majority of those with pollen had only one type, mostly from Centropogon. These results contrast with those from a one-year monitoring study (G. Avalos, unpublished) done in the same area in 1991, well before the feeders at La Georgina were established. That study recorded that two-to-three species of pollen were carried per hummingbird species, and a higher pollen load across all species. Furthermore, a sampling effort comparable to what we used here at sites 
TABLE 2

Distribution of captured hummingbirds across pollen load categories and sampling periods from 2003 to 2005 at La Georgina, Cerro de La Muerte, Costa Rica

\begin{tabular}{|c|c|c|c|c|}
\hline \multirow{2}{*}{ Sampling period } & \multicolumn{4}{|c|}{ Panterpe insignis } \\
\hline & High & Low & Empty & Total per Season \\
\hline 2003 wet season & - & $4(24)$ & $13(76)$ & 17 \\
\hline 2004 early dry season & $5(13)$ & $14(37)$ & $19(50)$ & 38 \\
\hline 2005 peak dry season & $7(28)$ & $2(8)$ & $16(64)$ & 25 \\
\hline 2005 peak wet season & $1(12)$ & - & $8(88)$ & 9 \\
\hline Total per pollen load category & $13(15)$ & $20(22)$ & $56(63)$ & $\mathrm{N}=89$ \\
\hline \multirow{2}{*}{ Sampling period } & \multicolumn{4}{|c|}{ Eugenes fulgens } \\
\hline & High & Low & Empty & Total per Season \\
\hline 2003 wet season & $2(14)$ & $5(36)$ & $7(50)$ & 14 \\
\hline 2004 early dry season & $2(40)$ & $1(10)$ & $2(40)$ & 5 \\
\hline 2005 peak dry season & $4(25)$ & $1(6)$ & $11(69)$ & 16 \\
\hline 2005 peak wet season & $2(12)$ & $2(12)$ & $13(76)$ & 17 \\
\hline Total per pollen load category & $10(19)$ & $9(18)$ & $33(63)$ & $\mathrm{N}=52$ \\
\hline \multirow{2}{*}{ Sampling period } & \multicolumn{4}{|c|}{ Colibri thalassinus } \\
\hline & High & Low & Empty & Total per Season \\
\hline 2005 peak dry season & $6(40)$ & $1(7)$ & $8(53)$ & 15 \\
\hline 2005 peak wet season & - & $2(40)$ & $3(60)$ & 5 \\
\hline Total per pollen load category & $6(30)$ & $3(15)$ & $11(55)$ & $\mathrm{N}=20$ \\
\hline \multirow{2}{*}{ Sampling period } & \multicolumn{4}{|c|}{ Selasphorus flammula } \\
\hline & High & Low & Empty & Total per Season \\
\hline 2003 wet season & - & - & 2 & 2 \\
\hline 2004 early dry season & - & - & 1 & 1 \\
\hline 2005 peak dry season & 1 & - & 3 & 4 \\
\hline 2005 peak wet season & & - & 3 & 3 \\
\hline Total per pollen load category & 1 & & 9 & $\mathrm{~N}=10$ \\
\hline
\end{tabular}

In parentheses percentage of total individuals captured per season ${ }^{1}$ (row totals) and per Pollen load category (column totals).

${ }^{1}$ Not calculated for $S$. flammula due to small sample size.

away from La Georgina, commonly returned 20 captures across all hummingbird species (Wolf et al. 1976). There have been no other major changes in the landscape, or in plant distribution since feeders were established. These same locations were used in the past in the vicinity of the Restaurant before the establishment of the feeders, and returned a larger number of captures. Nowadays, hummingbirds are rarely observed or captured in areas away from the Restaurant. It is likely that the distance between the control sites and the restaurant was not large enough to enable us to find a section of the hummingbird assemblage not influenced by the feeders, suggesting that feeders are affecting hummingbird distribution within an approximate $3 \mathrm{~km}$ radius from the feeder's location.

The seasonality of flowering phenology determined the competitive and antagonistic pattern between feeders and flowers found at Cerro de La Muerte. Here, Centropogon shrubs (both $C$. valerii and $C$. talamancensis) produce flowers continuously during the year, but it is in the dry season when this genus reaches a peak in flower production, along with more than 20 hummingbird-pollinated plants abundant at the site (Colwell 1973, Wolf et al. 1976). This explains the dry season increase in pollen loads associated 
TABLE 3

Distribution of pollen types and presence of mites on La Georgina hummingbirds, Cerro de La Muerte, Costa Rica from 2003 to 2005

\begin{tabular}{|c|c|c|c|c|c|}
\hline Pollen type/Mites & $\begin{array}{c}\text { Panterpe } \\
\text { insignis }\end{array}$ & $\begin{array}{l}\text { Colibri } \\
\text { thalassinus }\end{array}$ & $\begin{array}{l}\text { Eugenes } \\
\text { fulgens }\end{array}$ & $\begin{array}{l}\text { Selasphorus } \\
\text { flammula }\end{array}$ & $\begin{array}{l}\text { Total per } \\
\text { pollen type }\end{array}$ \\
\hline Bomarea & 1 & & & & 1 \\
\hline Cavendishia & & & 1 & & 1 \\
\hline Centropogon & 16 & 7 & 32 & 1 & 56 \\
\hline Fuchsia & 2 & 2 & 2 & & 6 \\
\hline Gaiadendron & 1 & & & & 1 \\
\hline Macleania & 7 & & 2 & & 9 \\
\hline Salvia & 1 & & & & 1 \\
\hline Mites present & & & 4 & & 4 \\
\hline Unknown 1 & 1 & & & & 1 \\
\hline Unknown 2 & 12 & & & & 12 \\
\hline Unknown 3 & 1 & & & & 1 \\
\hline Total per hummingbird species & 42 & 9 & 41 & 1 & 93 \\
\hline
\end{tabular}

with the decrease in feeder visitation. Inouye et al. (1991) observed a similar competitive and antagonistic pattern between feeders and flowers in the Broad-tailed Hummingbird (Selasphorous platycercus) in the Rocky Mountains of Colorado: in years of high flower abundance hummingbirds decreased the use of feeders, but in years of low flower abundance feeders drew hummingbirds away from flowers. Similar results were found by McCaffrey \& Wethington (2008) in a hummingbird assemblage in Southeastern Arizona.

The competitive and antagonistic pattern shown here between feeders and flowers indicate that pollination networks could be significantly altered. Feeders present a superabundant, predictable resource, whose availability does not decrease throughout the day or seasons, as is the case with hummingbird pollinated plants (Hainsworth \& Wolf 1972, Wolf et al. 1976, Garrison \& Gass 1999). The long-term use of feeders may alter migration routes, the spatial dispersion of hummingbird assemblages, and behavioral interactions among hummingbird species. In at least one study it has been established that feeders decrease plant reproductive success (Arizmendi et al. 2007).

Our results need to be compared with more diverse hummingbird assemblages over longer periods. The harsh environmental conditions of the highlands (i.e., cold nights and hot and dry conditions during the day in the dry season, and cold nights and rainy days in the wet season) increases the importance of feeders for highland hummingbirds. In the lowlands and mid-elevations a more diverse plant assemblage and more favorable environmental conditions could favor a wider dispersal of hummingbirds over larger areas, decreasing dependence and opportunistic use of feeders. Preliminary observations done in June 2005 at the Monteverde cloud forest, Costa Rica, (G. Avalos, pers. obs.), showed that territorial trochilinidae hummingbirds, medium size and short-billed (i.e., Green-crowned Brilliant, Heliodoxa jacula, similar in size and overall morphology to $P$. insignis), tend to monopolize feeders more often than non-territorial hummingbirds, and that feeders are sparingly visited by trapliners (Green Hermit, Phaetornis guy). Thus, trochilinidae territorial hummingbirds are more likely to develop a strong dependence on feeders. Borgella et al. (2001) analyzed a more diverse hummingbird-plant assemblage, and found relatively high and diverse pollen loads for the Long-tailed Hummingbird (Phaetornis superciliosus), but just one pollen type for the White-tipped Sicklebill 
(Eutoxeres aquila). However, data were limited to the dry season of 1998 .

The actual effects of artificial feeders on pollination systems have been neglected in the literature. By supplementing birds with food we are prone to interfere with pollination networks already stressed by anthropogenic effects, such as global warming, habitat fragmentation, land use changes, and intense agricultural practices involving the use of pesticides and herbicides (Kearns et al. 1998). Healthy pollination systems perform a critical environmental service to humankind, but are rarely quantified, and much less, officially acknowledged. However, without knowledge on the basic aspects of plant-pollinator interactions and how these are affected by humans, it will be difficult to implement optimal management decisions for conservation (Ghazoul 2005).

\section{ACKNOWLEDGMENTS}

We thank the students and staff of The School for Field Studies and volunteers from the University of Costa Rica (Luis Sandoval, María Gabriela Gei, Sabrina Amador, Esteban Bermúdez, Katya Barrantes and Minor Barboza) for their help with fieldwork. We thank the staff and owners of La Georgina for their hospitality and for the opportunity to work there. Jorge Pérez-Emán and Nickolas Waser provided key input which significantly improved the manuscript. Mist nets were provided by the organization IDEAWILD.

\section{RESUMEN}

El uso de comederos constituye una práctica común para atraer colibríes, a pesar de que sabemos poco acerca de sus efectos sobre las relaciones ecológicas entre colibríes y sus plantas asociadas. Estudiamos el grupo de colibríes del Cerro de La Muerte, Costa Rica, en un sitio con comederos permanentes (Restaurante La Georgina), así como en un lugar alejado de los comederos. Analizamos cómo el uso y monipolización estacional de los comederos afectaba la carga de polen en cuatro períodos de muestreo entre 2003 y 2005. Esperábamos que las especies que monopolizaban los comederos tuvieran poco o cero polen, y si lo presentaban que la carga de polen estuviera representada por pocas especies en comparación con especies menos dependientes de los comederos. En la estación seca, la especie alfa Panterpe insignis, dominó los comederos. En la estación lluviosa el uso de comederos fue más equitativo. La carga de polen fue muy baja en abundancia (50\% de los colibríes tenían poco o cero polen) y diversidad (96\% de los colibríes tenían polen solamente del género Centropogon). Encontramos una relación competitiva y antagonística entre la visitación de comederos y la abundancia de flores. La carga de polen aumentó en la estación seca al haber más flores, aunque la mayoría de los colibríes capturados no tenían polen. Durante la estación lluviosa, cuando hay menos flores disponibles, el uso de comederos aumenta y la carga de polen disminuye. El uso de comederos interfiere en redes de polinización y se combina con otros efectos antropológicos negativos, tales como el calentamiento global, fragmentación de hábitats, cambio en el uso del suelo, que hacen más difícil la conservación de complejas redes tróficas.

Palabras clave: Panterpe insignis, Eugenes fulgens, Selasphorus flammula, Colibri thalassinus, Cerro de la Muerte, comederos artificiales, carga de polen, ecología de forrajeo.

\section{REFERENCES}

Altshuler, D.L. \& R. Dudley. 2002. The ecological and evolutionary interface of hummingbird flight physiology. J. Exp. Biol. 205: 2325-2336.

Arizmendi, M.C., C. Monterrubio-Solís, L. Juárez, I. Flores-Moreno \& E. López-Saut. 2007. Effect of the presence of nectar feeders on the breeding sucess of Salvia mexicana and Salvia fulgens in a suburban park near Mexico City. Biol. Conserv. 136: 155-158.

Bleiweiss, R. 1998. Origin of hummingbird faunas. Biol. J. Linn. Soc. 65: 77-97.

Borgella, R., A.A. Snow \& T.A. Gavin. 2001. Species richness and pollen loads of hummingbirds using forest fragments in southern Costa Rica. Biotropica 33: 90-109.

Brice, A.T. 1992. The essentiality of nectar and arthropods in the diet of the Anna's hummingbird (Calypte anna). Comp. Biochem. Phys. A 101: 151-155.

Colwell, R.K. 1973. Competition and coexistence in a simple tropical community. Am. Nat. 107: 737-760.

Garrison, J.S.E. \& C.L. Gass. 1999. Response of a traplining hummingbird to changes in nectar availability. Behav. Ecol. 10: 714-725.

Ghazoul, J. 2005. Buzziness as usual? Questioning the global pollination crisis. TREE 20: 367-373. 
Hainsworth, F.R. \& L.L. Wolf. 1972. Energetics of nectar extraction in a small, high altitude, tropical hummingbird, Selasphorus flammula. J. Comp. Physiol. 80: 377-387.

Hainsworth, F.R., B.G. Collins \& L.L. Wolf. 1977. The function of torpor in hummingbirds. Physiol. Zool. 50: $215-222$.

Inouye, D.W., W.A. Calder \& N.M. Waser. 1991. The effect of floral abundance on feeder censuses of hummingbird populations. Condor 93: 279-285.

Kearns, C.A., D.W. Inouye \& N.M. Waser. 1998. Endangered mutualisms: The conservation of plant-pollinator interactions. Annu. Rev. Ecol. Syst. 29: 83-112.

McCaffrey, R.E. \& S.M. Wethington. 2008. How the presence of feeders affects the use of local floral resources by hummingbirds: A case study from southern Arizona. Condor 110: 786-791.

Poulin, B., G. Lefebvre \& R. McNeil. 1992. Tropical avian phenology in relation to abundance and exploitation of food resources. Ecology 73: 2295-2309.
Powers, D.R. 1987. Effects of variation in food quality on the breeding territoriality of the male Anna's Hummingbird. Condor 89: 103-111.

Sandlin, E.A. 2000. Cue use affects resource subdivision among three coexisting hummingbird species. Behav. Ecol. 11: 550-559.

Stiles, F.G. 1980. The annual cycle in a tropical wet forest hummingbird community. Ibis 122: 322-343.

Stiles, F.G. 1995. Behavioral, ecological and morphological correlates of foraging by arthropods by the hummingbirds of a tropical wet forest. Condor 97: 853-878.

Stiles, F.G. \& A.F. Skutch. 1989. A guide to the birds of Costa Rica. Cornell University, Ithaca, New York, USA.

Stromberg, M.R. \& P.B. Johnsen. 1990. Hummingbird sweetness preferences: Taste or viscosity? Condor 92: 606-612.

Wolf, L.L., F.G. Stiles \& F.R. Hainsworth. 1976. Ecological organization of a tropical high-land hummingbird community. J. Anim. Ecol. 32: 349-379. 
